\title{
Distribution of the spotted minnow (Galaxias maculatus (Jenyns, 1842)) (Teleostei: Galaxiidae) in Western Australia including range extensions and sympatric species
}

\author{
David L. Morgan, Andrew Chapman, Stephen J. Beatty and Howard S. Gill \\ Centre for Fish and Fisheries Research, Murdoch University, South Street, Murdoch, Western Australia 6150
}

\begin{abstract}
Galaxias maculatus was captured from a number of rivers outside its previously known range. In Western Australia, it was formerly only known from rivers and lakes between the Goodga River (Two People's Bay, $30 \mathrm{~km}$ east of Albany) and the Dailey River (50 km east of Esperance), with additional records from the Boat Harbour Lakes (Kent River). An intensive survey of the inland fishes in rivers and lakes along the south coast of Western Australia has extended its distribution east by $50 \mathrm{~km}$ (Thomas River), west by approximately $40 \mathrm{~km}$ (Walpole River) and north by $400 \mathrm{~km}$ (Harvey River). The Western Australian Museum also has a specimen from the Canning River, a further $100 \mathrm{~km}$ north. Field salinity tolerance of $G$. maculatus was high, with fish found alive in $81 \mathrm{mScm}^{-1}(\sim 45 \mathrm{ppt})$. The freshwater piscifauna east of, and including, the Pallinup River is depauperate, with $G$. maculatus being the only freshwater species present. All sympatric teleosts are tolerant of salinity and, with the exception of the introduced Gambusia holbrooki, are estuarine, including Pseudogobius olorum, Leptatherina wallacei and Acanthopagrus butcheri.
\end{abstract}

\section{INTRODUCTION}

The Spotted Minnow, Common Galaxias or Common Jollytail (Galaxias maculatus (Jenyns, 1842)) is a small, elongate, partially translucent, scaleless, osmeriform fish (Figure 1). It is one of the most widely distributed freshwater fishes in the world (Berra et al. 1996; Waters et al. 2000), with populations occurring in Australia, Lord Howe Island, New Zealand, Chatham Islands, Falkland Islands and South America. Both landlocked (i.e. complete their life-cycle in inland waters) and catadromous (with a marine larval phase) populations are recognised, and this widespread distribution has been attributed to the presence of catadromous populations throughout its range in eastern Australia, New Zealand and South America, with the larvae moving into the sea after hatching (Benzie 1968; Pollard 1971; McDowall et al. 1975). The presence of $G$. maculatus in Western Australia was first reported by Coy (1979) and McDowall and Frankenberg (1981), where the distribution was thought to extend from the Goodga River in the west to the streams around Esperance (see Figure 2). Jaensch (1992) later reported a single specimen to the west of the Goodga River in the Boat Harbour Lakes (Kent River) (Jaensch 1992) (Figure 2).

This paper presents new data on the distribution of G. maculatus within Western Australia and extends the range of the species in this State.

\section{MATERIALS AND METHODS}

This study focused on sampling the fish fauna in the rivers and lakes east of, and including, the Pallinup River on the south coast of Western Australia, excluding estuaries. Fish were sampled primarily using a combination of fine mesh seine nets in 148 sites between the Pallinup River and Poison Creek (east of the Thomas River, see Figure 2). Data presented in Morgan et al. (1998) were used for the distribution of G. maculatus to the west of the Pallinup River, while the unpublished reports by Morgan and Beatty $(2003 a, b)$ were utilised for the occurrences of G. maculatus in the Walpole and Harvey rivers, respectively.

Species distribution maps were created using site latitude and longitude data in the program MapInfo (MapInfo Corporation 1998).

Dissolved oxygen, temperature and conductivity were measured in situ with a WTW Multiline P4 meter. Unless otherwise stated, measurements were made immediately below the water surface.

\section{RESULTS}

\section{Distribution of Galaxias maculatus in Western Australia}

During this study G. maculatus was captured from the following rivers and lakes within its previously known range: Goodga and Angove 


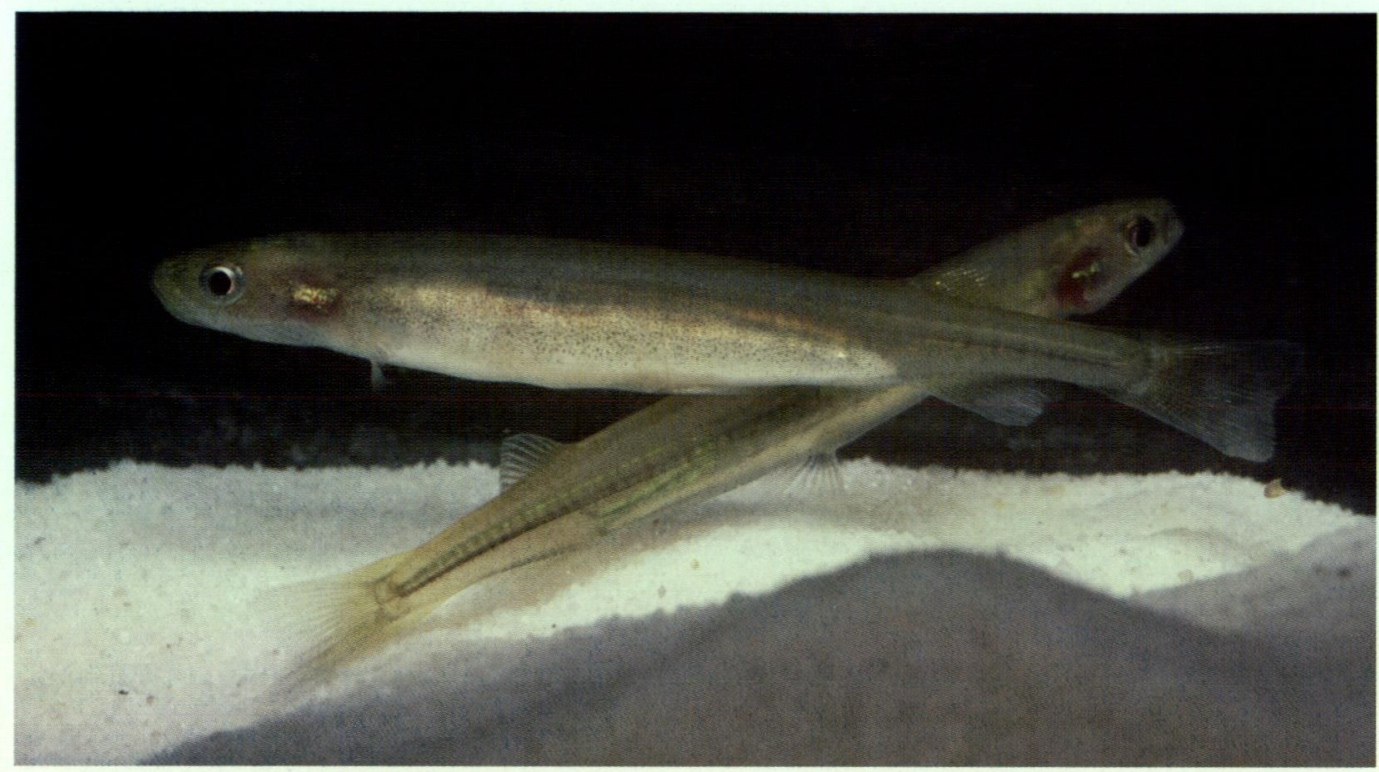

Figure 1 The spotted minnow (Galaxias maculatus).

rivers (Morgan et al. 1998), Pallinup, Bremer, Gairdner, Fitzgerald, Hamersley, Phillips, Steere, Jerdacuttup, Oldfield, Munglinup, Torradup, Young, Lort and Dalyup rivers; Yallobup, Kateup, Coramup and Bandy creeks; Moates, Gardner, Angove, Wheatley, Mullet and Woody lakes (Figure 2). Additionally, G. maculatus was captured from: Lake Boolenup and the Thomas River, approximately $100 \mathrm{~km}$ east of Esperance; the Walpole River, approximately $140 \mathrm{~km}$ west of the Goodga River; and in a drainage canal of Bancell Brook, a tributary of the Harvey River, approximately $580 \mathrm{~km}$ west and north from the Goodga River by coast (Figure 2).

\section{Sympatric species}

The estuarine Swan River Goby (Pseudogobius olorum) was found in the majority of systems between the Pallinup and Thomas rivers; the Western Hardyhead (Leptatherina wallacei) was found from the Pallinup River to Bandy Creek; Black Bream (Acanthopagrus butcheri), was captured with G. maculatus in the Oldfield River and in Wheatley and Woody lakes; and the introduced eastern Mosquitofish (Gambusia holbrooki) was found only in the Pallinup River (Figure 3).

\section{Environmental variables}

Galaxias maculatus was captured in conductivities ranging from 0.3 to $94.4 \mathrm{mScm}^{-1}$, and temperatures from 12 to $30^{\circ} \mathrm{C}$, however, all fish found in conductivites greater than $88 \mathrm{mScm}^{-1}$ were dead, yet in all salinities $<81.6 \mathrm{mScm}^{-1}(\sim 45 \mathrm{ppt})$ they were alive. Field measurements and repeated observations revealed that when dissolved oxygen levels were less than $1.5 \mathrm{mgl}^{-1}$ at $30 \mathrm{~cm}$ depth, $G$. maculatus approached the surface to respire aerially. In these instances the surface dissolved oxygen concentration was always marginally higher than that at $30 \mathrm{~cm}$. Furthermore, dead fish were recorded on several occasions when water temperatures were $>30^{\circ} \mathrm{C}$ and salinity was $<2 \mathrm{ppt}$.

\section{DISCUSSION}

During this study the range of G. maculatus was extended considerably, i.e. east to Lake Boolenup and the Thomas River, approximately $100 \mathrm{~km}$ east of Esperance; west to the Walpole River, approximately $140 \mathrm{~km}$ west of the Goodga River; and, in a drainage canal of Bancell Brook, a tributary of the Harvey River, approximately 580 $\mathrm{km}$ west and north from the Goodga River by coast (see Figure 2). The data presented here highlights the absence of studies of the inland fish fauna on the south coast of Western Australia.

There is a marked reduction in the number of species of native freshwater fish from west to east along the south coast of Western Australia. Ten freshwater fish species occur in the region with a moderate Mediterranean climate to the west of, but not including, the Pallinup River (Morgan et al. 1998; Allen et al. 2002), whereas only one freshwater species (i.e., G. maculatus) occurs in the region with a dry Mediterranean climate east of the Pallinup River (this study) (Figure 2). The ranges of G. maculatus and the estuarine $P$. olorum extend to the eastern most river on the south coast, i.e. the Thomas River (Figures 2 and 3), while the estuarine L. wallacei extends as far east as Bandy Creek. The species composition of the rivers east of, and including, the Pallinup River is a reflection of the higher natural salinities of these lower rainfall 


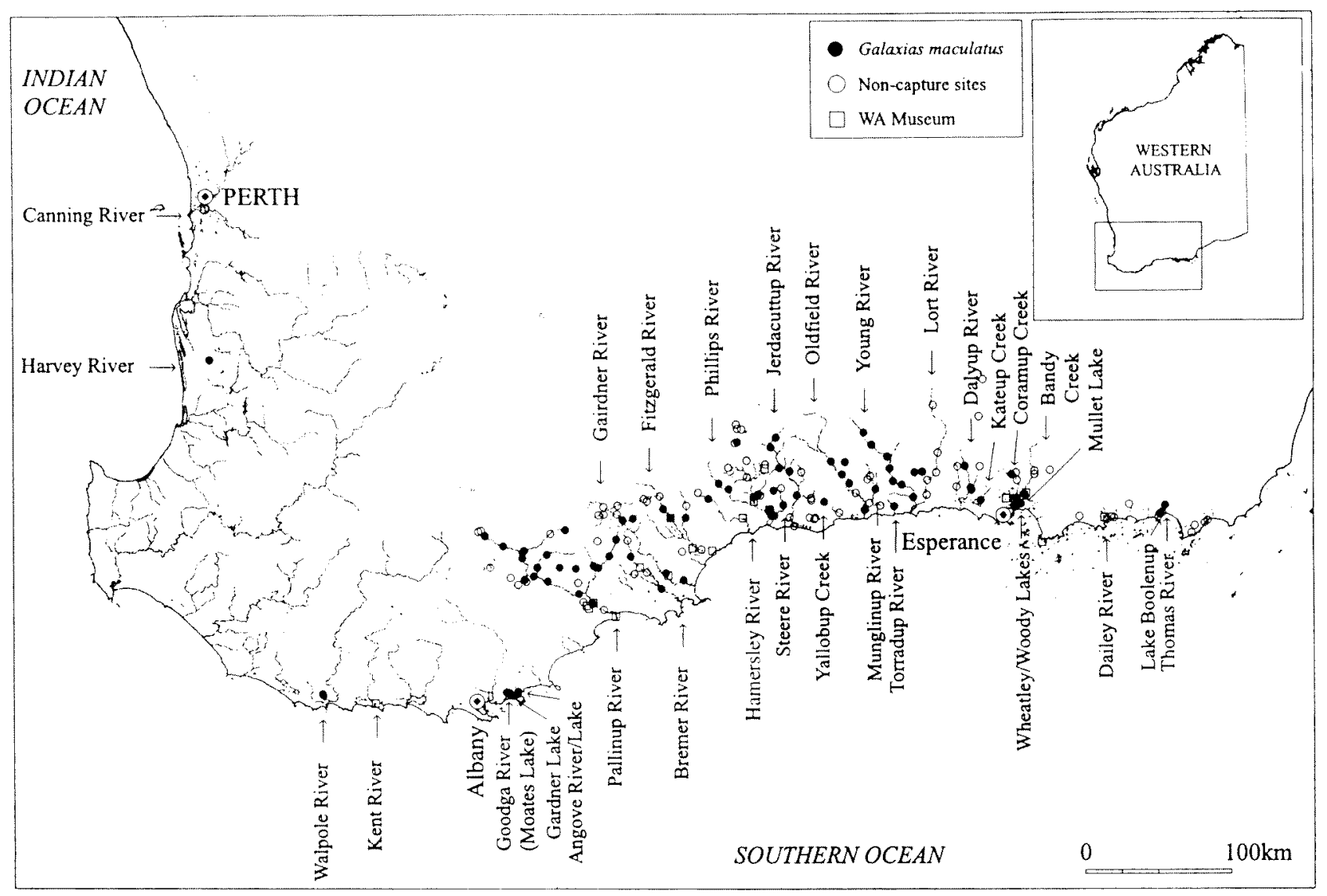

Figure 2 The sites that Galaxias maculatus were captured at during this study and from those specimens housed in the Western Australian Museum.

systems than for those rivers to the west. Thus, only species that are salt tolerant are found in the rivers east of the Pallinup. The feral G. holbrooki is able to tolerate salinities up to $\sim 60 \mathrm{ppt}$ (Morgan et al. 2004) but does not currently extend east of the Pallinup River however it is found in most of the river systems west of the Pallinup and north to the Hutt River, approximately $450 \mathrm{~km}$ north of Perth (see Morgan et al. 1998, 2004). This species is known to seriously impact other small south-western Western Australia fishes (Gill et al. 1999), yet it is not clear what impacts it has on the species in the Pallinup River. It is probably inevitable that it will eventually be introduced into other rivers on the south coast of Western Australia.

During the current study, the number of $G$. maculatus captured at those sites within its previously known range was far greater than those recorded to the west of its previously known range (i.e., Walpole and Harvey rivers), For example, despite extensive sampling, only four and one individuals were captured in the Walpole and Harvey rivers, respectively (Morgan and Beatty $2003 a, b)$. Therefore, these individuals, particularly in the case of those in the Harvey River, are either indicative of populations with very low abundances or are simply marine stragglers. It is likely that the establishment of new, self-maintaining populations is only achieved when adequate numbers migrate into these systems and environmental tolerances, particularly salinity and possibly temperature, are not exceeded. For example, while G. maculatus is extremely tolerant to high salinity (acute $\mathrm{LD}_{50}$ of 45 ppt, Chessman and Williams (1975) and supported by field observations in this study), water temperatures experienced on the west coast of Western Australia (e.g., Harvey and Canning rivers) may often exceed $30^{\circ} \mathrm{C}$ during summer, a temperature that Richardson et al. (1994) suggest is lethal to at least some New Zealand populations.

Previous workers have faced uncertainty whether Western Australian G. maculatus were land-locked or diadromous, though on the basis of an inland breeding record from the Pallinup River, the former was suspected (Allen 1982). A recent detailed study on the biology of $G$. maculatus in south-western Australia that included populations in the Goodga, Phillips, Oldfield and Jerdacuttup rivers confirms that, over most of its range in Western Australia, $G$. maculatus has a self sustaining, land-locked breeding strategy (Chapman 2004). Further evidence for this is the presence of fish in the 


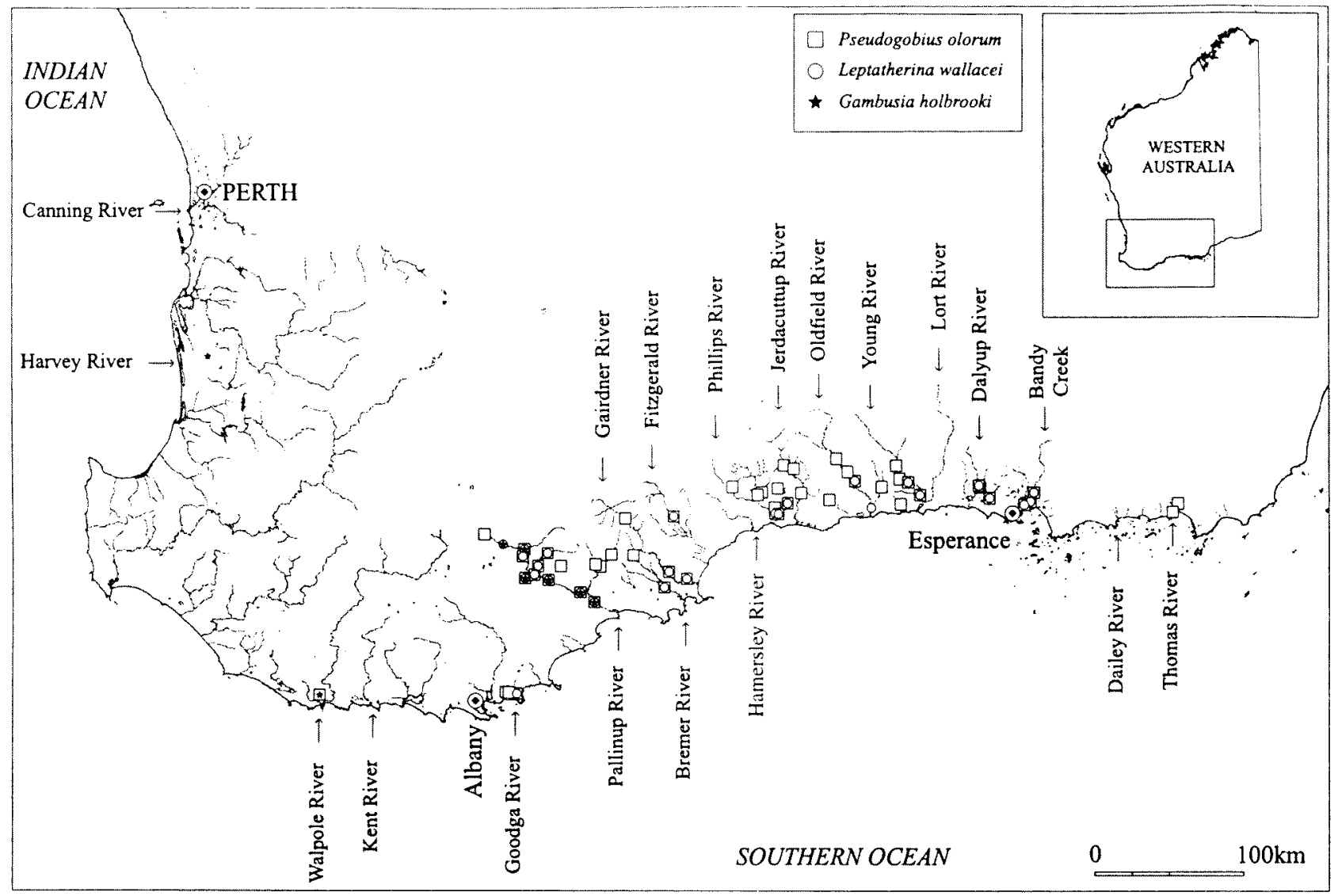

Figure 3 The distribution of the three sympatric species captured within the main range of Galaxias maculatus.

Jerdacuttup River, which has probably not had contact with the sea for 6000 years (Hodgkin and Clark 1990). In other rivers, occasional contact with the sea by either adult or larval fish is a possibility as raised beach bars can either be breached by flooding, vigorous winter flow or human intervention (artificial excavation).

McDowall (1988) considered that diadromous galaxiids represented the primitive or ancestral stock and that freshwater limited populations were a more recently derived phenomenon. Waters et al. (2000a) proposed that the loss of the primitive marine juvenile phase may be an important mechanism of galaxiid speciation. It is very likely then that on the south coast of Western Australia the land-locked strategy has developed from diadromous stock in response to changes to local coastal geomorphology over recent geological time, with most of the rivers of the region now being only intermittently open. For example, Culham Inlet, previously the Phillips River estuary, where $G$. maculatus is confirmed to undergo a land-locked life-history (Chapman 2004), was permanently open to the sea as recently as 3500 years ago but is now better described as a coastal salt lake (Hodgkin 1997). Most of the region's rivers are now open to the sea only after major rainfall events.
Although the presence of diadromous populations of G. maculatus in rivers on the south coast was not demonstrated during the present study, its presence in the Walpole River, which enters the sea via a permanently open channel at the mouth of the Nornalup Inlet (Hodgkin and Clark 1988), suggests that that there is at least the potential for diadromy in Western Australia.

Recent allozyme (Berra et al. 1996) and mitochondrial (Waters et al. 2000b) studies have demonstrated the considerable powers of dispersal, due to a marine larval stage in some populations, of G. maculatus. For example Berra et al. (1996) considered that gene flow continues to occur between Australia, New Zealand and South America, and whilst Waters et al. (2000b) confirmed gene flow between Australia and New Zealand, they were less convinced that dispersal occurred across the Pacific. It is likely that the presence of $G$. maculatus in the Walpole and Harvey rivers, is a result of larval drift via ocean currents from either outside Western Australia or from a south coast river. The collection of more mitochondrial data is required to test which of these hypotheses is the more likely. Such data would also permit comparisons of the genetic structure of populations within Western Australia, and between Western Australia, eastern Australia, New Zealand and 
South American populations, i.e. is there regular gene flow between systems?

\section{ACKNOWLEDGEMENTS}

We would like to thank the Natural Heritage Trust, Murdoch University, Department of Fisheries, Water and Rivers Commission, Harvey River Restoration Trust and Fishcare WA for providing funds towards this project. Thanks to CALM for providing permits to sample in National Parks and A Class Reserves. Thank you to Charlotte Morgan for help with sampling.

\section{REFERENCES}

Allen, G.R. (1982). A Field Guide to Inland Fishes of Western Australia. Western Australian Museum, Perth.

Allen, G.R., Midgley, S.H. and Allen, M. (2002). Field Guide to the Freshwater Fishes of Australia. Western Australia Museum, Perth.

Benzie, V. (1968). Some ecological aspects of the spawning behaviour and early development of the common whitebait Galaxias maculatus attenuatus (Jenyns). Proceedings of the New Zealand Ecological Society 15: 31-39.

Berra, T.M., Crowley, L.E.L.M., Ivantsoff, W. and Fuerst, P.A. (1996). Galaxias maculatus: an explanation of its biogeography. Marine and Freshwater Research 47: 845849.

Chapman, A. (2004). Biology of the spotted minnow Galaxias maculatus (Jenyns 1842) (Pisces: Galaxiidae) on the south coast of Western Australia. MSc Thesis. Murdoch University, Perth, Western Australia.

Chessman, B.C. and Williams, W.D. (1975). Salinity tolerance and osmoregulatory ability of Galaxias maculatus (Jenyns) (Pisces, Salmoniformes, Galaxiidae). Freshwater Biology 5: 135-140.

Coy, N. J. (1979). Freshwater Fishing in South-West Australia. Jabiru Books, Perth

Gill, H.S., Hambleton, S.J. and Morgan, D.L. (1999). Is Gambusia holbrooki a major threat to the native freshwater fishes of south-western Australia? In B. Seret and J.-Y. Sire (eds) Proceedings 5th Indo-Pacific Fish Conference (Noumea, 3-8 November 1997), pp. 79-87, Societe Francaise d'Ichtyologie et Institut de Recherche pour le Development, Paris.

Hodgkin, E.P. (1997). History and management of Culham Inlet, a coastal salt lake in south-western Australia. Journal of the Royal Society of Western Australia 80: 239-247.

Hodgkin, E.P. and Clark, R. (1988). Estuaries and Coastal Lagoons of south Western Australia - Nornalup and Walpole inlets and the estuaries of the Deep and Frankland rivers. Estuarine Studies Series No. 2. Environmental Protection Authority, Perth.
Hodgkin, E.P. and Clark, R. (1990). Estuaries of the Shire of Ravensthorpe and the Fitzgerald River National Park. Estuarine Studies Series No. 7. Environmental Protection Authority, Perth.

Jaensch, R.P. (1992). Fishes in Wetlands on the South Coast of Western Australia. Unpublished Technical Paper. Department of Conservation and Land Management Western Australia, Perth.

Mapinfo Corporation (1998). Mapinfo professional- user's guide. Mapinfo Corporation, New York.

McDowall, R.M. (1988). Diadromy in Fishes: Migrations Between Freshwater and Marine Environments. Croom Helm, London.

McDowall, R.M. and Frankenberg, R.S. (1981). The galaxiid fishes of Australia (Pisces: Galaxiidae). Records of the Australian Museum 33: 443-605.

McDowall, R.M., Robertson, D.A. and Saito, R. (1975). Occurrence of galaxiid larvae and juveniles in the sea. New Zealand Journal of Marine and Freshwater Research 9: 1-9.

Morgan, D. and Beatty, S. (2003a). Freshwater fishes of the Walpole River and impact of the weir to fish and lamprey migrations. Unpublished report to Fisheries Western Australia.

Morgan, D. and Beatty, S. (2003b). Fish and decapod fauna of Bancell Brook (Harvey River) and the impacts of irrigation slot boards on migrations. Unpublished report to the Southern Peel Partnership Landcare Group.

Morgan, D.L., Gill, H.S., Maddern, M.G. and Beatty, S.J. (2004). Distribution and impacts of introduced freshwater fishes in Western Australia. New Zealand Joumal of Marine and Freshwater Research 38: 511-523.

Morgan, D.L., Gill, H.S. and Potter, I.C. (1998). Distribution, identification and biology of freshwater fishes in south-western Australia. Records of the Western Australian Museum Supplement No. 56: 97 pp.

Pollard, D.A. (1971). The biology of a land-locked form of the normally catadromous salmoniform fish Galaxias maculatus (Jenyns) I. Life cycle and origin. Australian Journal of Marine and Freshwater Research 22: 91-123.

Richardson, J, Boubée, J.A.T. and West, D.W. (1994). Thermal tolerance of some native New Zealand freshwater fish. New Zealand Journal of Marine and Freshwater Research 28: 399-407.

Waters, J.M., Dijkstra, L.H. and Wallis, G.P. (2000b). Biogeography of a southern hemisphere freshwater fish: how important is marine dispersal? Molecular Ecology 9: 1815-1821.

Waters, J.M., Lopez, J.A. and Wallis, G.P. (2000a). Molecular phylogenetics and biogeography of galaxiid Fishes (Osteichthyes: Galaxiidae): dispersal, vicariance, and the position of Lepidogalaxias salamandroides. Systematic Biology 49: $777-795$.

Manuscript received 19 January 2004; accepted 23 March 2005 